УДК 159.942

https://doi.org/10.31392/NPU-nc.series12.2020.9(54).12

\title{
ОСОБЛИВОСТІ ЕКСПРЕСІЇ ОСІБ 3 РІЗНОЮ СХИЛЬНІСТЮ ДО АЛЕКСИТИМІї
}

\author{
Ольга Саннікова \\ доктор психологічних наук, професор, \\ завідувач кафедри загальної та диференціальної психології \\ Державний заклад «Південноукраїнський національний \\ педагогічний університет імені К. Д. Ушинського» \\ 65020, Україна, м. Одеса, вул. Старопортофранківська, 26 \\ osanniland@gmail.com, http://orcid.org/0000-0003-3961-2103 \\ Жень Чжун \\ аспірант кафедри загальної та диференціальної психології \\ Державний заклад «Південноукраїнський національний \\ педагогічний університет імені К. Д. Ушинського» \\ 65020, Україна, м. Одеса, вул. Старопортофранківська, 26 \\ 903843223@qq.com
}

\section{Анотація}

Статтю присвячено проблемі розпізнавання власних емоційних переживань та їх зовнішніх виразів. Схильність особистості до розпізнавання емоцій через сприйняття експресії розглядається як усталена, багатокомпонентна, інтегральна властивість, що забезпечує точність, адекватність розуміння своїх емоційних переживань і переживань іншого. Актуальність розробки проблеми пов'язана з дефіцитом соціальних зв'язків, відсутністю досвіду в розпізнаванні емоцій, особливо в ситуації розвитку ІнтернетКомунікацій, що призводить до редукції емоційної лексики сучасної людини. Процес соціальної адаптації неможливий без здатності особистості розуміти та диференціювати емоції. Це спричинює необхідність вивчення здатності особистості до адекватного визначення власних емоційних станів і розуміння власного експресивного репертуару. Дослідження грунтується на припущенні, що труднощі розпізнавання власних емоцій та їх експресивних виявів можуть бути пов'язані 3 різною схильністю особистості до алекситимії. Алекситимія розглядається як нездатність сприймати, відчувати і називати словом (lexis) свої почуття, свої емоції (thymos).

Мета роботи полягає у дослідження здатності до розуміння та розпізнавання власних експресивних проявів емоцій в осіб, котрі різняться схильністю до алекситимії. Розкрито поняття алекситимії як чинника розуміння емоцій; вивчено співвідношення між показниками означених змінних; виявлено осіб, схильних і не схильних до алекситимії, та визначено й порівняно особливості їх експресії. Емпірично встановлена наявність значимого від'ємного зв'язку між показниками виразної експресії та алекситимії. Показано, що тенденція до збільшення рівня алекситимії гальмує здатність особистості до експресивних проявів власних емоційних переживань, а прояви успішного розпізнавання власної експресії демонструють особи, котрі не виявили схильності до алекситимії. Доведено, що схильність до алекситимії є одним із психологічних чинників здатності особистості не тільки розуміти власні емоції, а й здатності ідентифікувати i 
використовувати власний експресивний репертуар, його можливості та ресурси.

Ключові слова: алекситимія, експресія, емоції, алекситимічний тип, неалекситимічний тип, розпізнавання емоцій.

\section{Вступ}

Актуальність розробки проблеми пов'язана, перш за все, 3 тими стрімкими змінами, що відбуваються у сучасному суспільстві, зокрема, 3 появою і розвитком всесвітньої мережі Інтернет, котра забезпечує певні можливості інтернет-спілкування та обміну інформацією. Негативним наслідком інтернет-практик стає надмірна залежність від них користувачів, захопленість соціальними мережами, що порушує спілкування, призводить до дефіциту соціальних комунікацій і відсутності досвіду в розпізнаванні емоцій. Відомо, що процес соціальної адаптації неможливий без здатності особистості тонко підмічати, розуміти, розпізнавати, ідентифікувати емоційні переживання і власні, $\mathrm{i}$ співрозмовників. Ця здатність $є$ однією із провідних якостей особистості спеціалістів у галузі соціономічних професій (психологів, акторів, лікарів, вчителів, менеджерів та ін.). Точне розпізнавання емоцій, адекватна інтерпретація їх проявів є ключовою умовою успішної комунікації й підтримки позитивних міжособистісних відносин. Успішне розпізнавання емоцій іншого неможливе без здатності до адекватного визначення власних емоційних станів, без розуміння власного експресивного репертуару, без розвиненої здатності передавати за допомогою невербального виразу внутрішній емоційний світ особистості. Саме ці міркування спрямували наше дослідження на вивчення особливостей розпізнавання власних емоційних станів і розуміння власного експресивного репертуару.

Експресія розуміється як мова виразності, що закладена в міміці людської особистості, інтонації голосу, у пантоміміці, жестах, рухах, позах, ході людини (Ольшанникова, 1981; Лабунская \& Дроздова, 2003; Izard, 1971). Експресія людини, 3 одного боку, є каналом спілкування, який передає додаткову інформацію про особливості характеру, про ставлення до інших людей, про напрям думок людини тощо. 3 іншого боку, експресія - це зовнішній вираз емоцій, індикатор, за допомогою якого можна судити про особливості переживань людини. Звичайно ж, і культура, i соціальне оточення, i саморегуляція деякою мірою можуть або приховувати, «затушовувати», або, навпаки, «оголювати» емоційні переживання зовнішніми експресивними проявами. Отже, зовнішні експресивні вияви не завжди відповідають внутрішнім переживанням, що значно ускладнює розпізнавання емоцій (Санникова, 2003).

Розпізнавання емоцій досить розроблена область психології. Детально досліджено різні аспекти розпізнавання емоцій, такі як виділення ознак, за якими люди судять про емоції, крос-культурна універсальність і специфічність сприйняття емоцій, зв'язок 3 індивідуальними психологічними особливостями тощо (Мацумото, 2003). У контексті наших інтересів, наприклад, такі дослідники як П. Екман, В. Фризен, С. Томкінс вважають, що національні, расові, релігійні особливості спостерігача не суттєво впливають на точність і частоту розпізнавання базисних емоцій саме за виразом обличчя (Ekman, Friesen \& Tomkins, 1971). Януш Рейковський зазначає, що мімічний вираз емоцій людини відбиває як вроджені видотипові мімічні схеми, так і набуті соціалізовані способи вияву емоцій та індивідуальні особливості експресії, що властиві лише даному індивідові (Рейковский, 1979). Серед чинників здатності розуміти й розпізнавати емоції 
розглядається професійна діяльність людини, особливо якщо вона пов'язана 3 міжособистісною взаємодією. Вивчаючи точність розпізнавання емоційної експресії в усному іншомовному повідомленні в різних професійних групах, у роботах А. А. Жежелевської (Жежелевская, 2014: 80) встановлено, що актори точніше розпізнають емоційну експресію у порівнянні з інженерами та педагогами. Автор пояснює це тим, що уміння входити в образ, відчувати й розуміти переживання своїх героїв $є$ невід'ємною частиною акторської майстерності. В емпіричних дослідженнях Т. В. Корнєва та Е. Ф. Бажина (Корнева \& Бажин, 1977) було встановлено, що лікарі-психіатри більш точно розпізнають емоції, ніж математики й інженери. У роботах І. Б. Есіна (Есін, 2006) показано, що актори й вокалісти як представники творчих професій більш успішно та скрупульозно диференціюють емоції інших людей за характеристиками голосу, його інтонацією, тембром тощо, ніж програмісти й фізики. М. Непп і Д. Хол (Непп \& Холл, 2006) довели, що клінічні психологи у розпізнаванні емоцій більш успішні ніж вчителі. Як чинники, що лежали в основі вміння «читати» експресивні повідомлення іншого, досліджуються різні усталені характеристики особистості обстежуваних, такі як виразність особистісних рис, наявність будь-якого афективного розладу (депресії або фобіiі), стать тощо (Luebbe et al., 2013; McClure, 2000). Вважається також, що точність розпізнавання емоцій може залежати не тільки від стійких, але й від мінливих, ситуативно зумовлених, поточних емоційних станів (Овсянникова, 2014). Вивчаючи причини алекситимії I. М. Андреєва фіксує увагу на соціальних чинниках, до яких відносить: сімейні заборони на вираз почуттів, прагнення до максимальної соціальної адаптації, до ригідного наслідування соціальних норм. На думку автора, людина зневажає особистими потребами на користь групових (сімейних) вимог, а, оскільки емоції - це суб'єктивна форма виявлення потреб, то їй доводиться жертвувати й своїми переживаннями та їх зовнішніми виразами (Андреева, 2011), що проявляється у скудності експресії. Серед чинників ідентифікації емоційних переживань також виділяють широкий спектр рис особистості: емоційний інтелект (Носенко \& Коврига, 2003), психологічну проникливість, експресивність тощо (Саннікова, 2017).

Усі ці чинники впливають на точність розпізнавання не тільки чужих емоційних переживань та відповідної експресії, а й своїх, без яких неможливо пізнати емоційний світ іншої людини. Виникає питання, чи можна очікувати від людини, яка добре (або погано) розуміє власні емоційні переживання, що вона так само добре буде презентувати їх зовні, тобто, транслювати їх через експресію та адекватно їх оцінювати? Наше дослідження грунтується на припущеені, що адекватність оцінки власних емоцій та їх експресивних виявів може бути спричинена індивідуально-психологічними особливостями особистості, зокрема, алекситимією.

Термін «алекситимія» («почуття без слів») був запропонований американським психіатром Пітером Сифнеосом (Peter Emmanuel Sifneos) iз Массачусетського госпіталя у Бостоні в 1968 році (Nemiah J.C. et al., 1976). хоча це явище було відоме і раніше. Алекситимія - особистісний конструкт, що згодом був валідизований із застосуванням психометричних методик (Taylor, Bagby \& Parker, 1997) і різних експериментальних підходів (Lane, Sechrest, Reidel et al., 1996; Suslow \& Junghanns, 2002).

Алекситимія розглядається як сукупність ознак, що характеризують психічний склад індивіда, які виявляються у низькому розумінні власних емоцій, відсутності 
здатності до усвідомлення, розпізнавання своїх емоцій, у низькій здатності контролювати зовнішні прояви своїх емоцій і характеризується низьким рівнем диференціації й вербалізації афектів, котрі не сприяють ефективному спілкуванню. Основними характеристиками алекситимії є: труднощі ідентифікації, диференціювання почуттів, тілесних відчуттів, що виникають при емоційному переживанні; труднощі в повідомленні про свої почуття іншим особам; недостатньо розвинений процес уяви, орієнтований на зовнішні стимули; когнітивний стиль. Вважається, що всі ці ознаки відбивають дефіцит когнітивної переробки й регуляції емоцій (Taylor, Bagby \& Parker, 1997). Складність у вербальному символічному виразі емоцій, у словесному описі свого стану, відбилася у назві даного феномена. Алекситимія - це нездатність сприймати, відчувати і називати словом (lexis) свої почуття, свої емоції (thymos). Можна стверджувати, що особистість, яка утруднюється в позначенні власних переживань, навряд чи зможе вербалізувати емоційні стани й властивості іншої людини, i, навряд чи зможе за допомогою власної експресії розкрити іншому свій емоційний світ.

Мета дослідження полягає у вивченні здатності до розуміння та розпізнавання власних експресивних проявів емоцій в осіб, котрі різняться схильністю до алекситимії. Досягнення мети передбачало вирішення таких завдань: 1) розкрити поняття алекситимії як чинника розпізнавання власних емоцій і єкспресії; 2) емпірично дослідити рівень схильності до алекситимії та особливості зовнішніх виявів власних емоцій (експресії); 3) вивчити співвідношення між показниками цих змінних; 4) виявити осіб схильних і не схильних до алекситимії, визначити та порівняти особливості їх експресії.

\section{Методи дослідження}

Для вимірювання показників зовнішніх емоційних виразів застосовувався тестопитувальник «Експрес-діагностика емоційної експресії» (самооцінний варіант) (Санникова, 1982). Перший варіант опитувальника з емоційної експресії був створений Е. В. Богіною під керівництвом і при особистій участі А. Е. Ольшаннікової (Ольшанникова, 1981: 124-136). Цей варіант методики створювався як один з інструментів набору портативних методик, спрямованих на діагностику індивідуально-стійких особливостей емоційності. Надалі методика була модифікована й доповнена одним із авторів даної статті (Санникова, 1982; 2009). Остання апробація модифікованого варіанту методики здійснювалася у 2017 році.

Тест-опитувальник експресії в сучасному варіанті складається 348 питань, спрямованих на діагностику: а) восьми каналів експресії (гучність голосу, темп мови, образність мови, помилки мови, інтонаційний вираз мови, загальна рухова активність, зайві рухи, міміка; б) виразності чотирьох базальних емоційних модальностей (паттернів емоцій: радість, гнів, страх, печаль); в) недиференційованої виразності (без диференціації каналів), загального показника експресивності особистості (Санникова, 1982; 2009). За допомогою цієї методики, що заснована на самооцінці, діагностується не саме емоційне переживання, а його зовнішній прояв, його вираз, мимовільна емоційна експресія. Таким чином, ця методика розрахована на одержання інформації: про специфіку каналів мимовільної експресї̈; про особливості експресї̈, яка супроводжує переживання різних емоційних модальностей; про загальний ступінь експресивності, незалежно від модальності переживань і каналів їх прояву. Саме цей варіант методики був залучений у 
нашому досліджені. Задля діагностики алекситимії використовувалася Торонтська алекситимічна шкала 326 пунктів (Toronto Alexithymia Scale - TAS-26), що була запропонована в 1985 p. G. Taylor із співавторами (Taylor, Ryan \& Bagby, 1985). Численні дослідження із застосуванням TAS довели стабільність, надійність і валідність іiі факторної структури й відповідно результатів, що одержувались. TAS-26 складається з 26 питань, деякі з яких інтерпретуються у прямих значеннях, деякі - у зворотніх. Це, на думку авторів, дозволяє знизити установність відповідей обстежених. В оригінальному варіанті цей тест не має внутрішніх субшкал, тому результат має тільки одне значення загальний рівень алекситимії. За допомогою комп'ютерної програми SPSS 21.0 for Windows здійснювалася математично-статистична обробка даних, а, саме, застосовувались методи кількісного (кореляційний аналіз, t-критерій Ст'юдента) та якісного аналізу даних (метод «асів», «профілів»).

\section{Результати та дискусії}

Загальний задум емпіричної частини нашого дослідження полягав у тому, щоб діагностувати особливості емоџійної експресї у обстежуваних, котрі різною мірою схильні до алекситимії. Ми спиралися на припущення про те, що схильність до алекситимії є одним із психологічних чинників здатності особистості не тільки розуміти власні емоції, а й здатності ідентифікувати та використовувати власний експресивний репертуар, його можливості, ресурси. Конкретно очікується, що рух до алекситимії (тенденція) гальмує, блокує здатність особистості до експресивних проявів власних емоційних переживань. Очікується також наявність значимого від'ємного зв'язку між цими змінними (виразна експресія й алекситимія) та прояви успішного розпізнавання власної експресії в осіб, які не виявили схильність до алекситимії, що буде свідчити на користь теоретичного припущення. Емпіричне дослідження проводилося протягом 20182019 років. У ньому приймали участь 95 студентів Державного закладу «Південноукраїнський національний педагогічний університет імені К. Д. Ушинського» у віці 20-25 років.

У табл. 1 презентовано значимі коефіцієнти кореляцій між загальним показником алекситимії й окремими показниками емоційної експресії.

Таблиия 1

Коефіцієнти кореляцій між алекситимісю та емоційною експресією

\begin{tabular}{|l|c|c|c|c|c|c|c|c|c|c|}
\hline & \multicolumn{10}{|c|}{ Показники експресії } \\
\cline { 2 - 11 } & $\Gamma Г$ & ТМ & ОМ & ІнМ & РА & Р & С & П & НдК & ЗПЕ \\
\hline АЛТ & -220 & -228 & $-321^{*}$ & $-290^{*}$ & $-280^{*}$ & -212 & 260 & 248 & $-325^{*}$ & -207 \\
\hline
\end{tabular}

Примітка: 1) N = 95; нулі та коми опущені; позначення «*» свідчить про 1\% рівень взаємозв'язку $(\rho \leq 0,01)$, без позначення - 5\% $(\rho \leq 0,05) .2)$ скорочення показників, що презентовані у табл. 1: а) АЛТ - показник алекситимії; б) канали експресії: ГГ - гучність голосу, ТМ - темп мови, ОМ - образність мови, ПМ - помилки мови, ІнМ - інтонаційний вираз мови, РА - загальна рухова активність, ЗР - зайві рухи, М - міміка; в) виразність емоційних модальностей: $\mathrm{P}$ - радість, Г - гнів, С - страх, П - печаль; г) НдК - без диференціації каналів, ЗПЕ - загальний показник експресивності особистості.

Аналіз табл. 1 свідчить про те, що показник алекситимії має переважно від’ємні 
значимі взаємозв'язки, на рівні і 5\%, і 1\%, 3 більшістю показників експресії, за виключенням показників, що несуть інформацію про зовнішні вияви емоційних модальностей С (страх) і П (печаль, сум). 3 цими показниками показник алекситимії пов'язаний додатно $(\rho \leq 0,05)$. Ці результати підтверджують дані, що існують у літературі про те, що особи з алекситимією схильні до недиференційованих негативних емоцій (Taylor, Bagby \& Parker, 1997). Крім того, слід зазначити, що з такими показниками експресії, як ПМ (помилки мови), ЗР (зайві рухи), М (міміка) та Г (гнів) значимих взаємозв'язків не виявлено.

Задля розуміння взаємозв'язків, що нами отримані, та для розв'язання поставлених завдань, визначимо особливості експресії осіб схильних і не схильних до алекситимії. 3 цією метою проведемо якісний аналіз даних із застосуванням методу «асів» і «профілів». Для цього, попередньо «сирі бали» показників обраховувалися у процентілі, задля отримання кривої розподілу, що наближається до нормальної.

Важливо наголосити, що у вибірці наших обстежуваних, максимальних значень за шкалою алекситимії практично не виявлено. Саме тому, із усієї вибірки обстежуваних емпірично було виділено лише 2 групи осіб. Перша група осіб $(\mathrm{N}=9)$ виявила тенденцію до алекситимічного типу особистості (група ризику) і включала обстежуваних із числовими значеннями даного показника в діапазоні від 50 до 80 процентилей (переважно третій квартиль розподілу та на границі із четвертим). Другу групу $(\mathrm{N}=12)$ - склали особи з низькими значеннями показника алекситимії (від 1 до 25 процентиля, значення розташовуються переважно в просторі першого квартиля розподілу), котрих віднесено до неалекситимічного типу особистості.

Отже, розглянемо профілі показників експресії осіб, які різняться схильністю до алекситимії, що презентовано на рис. 1.

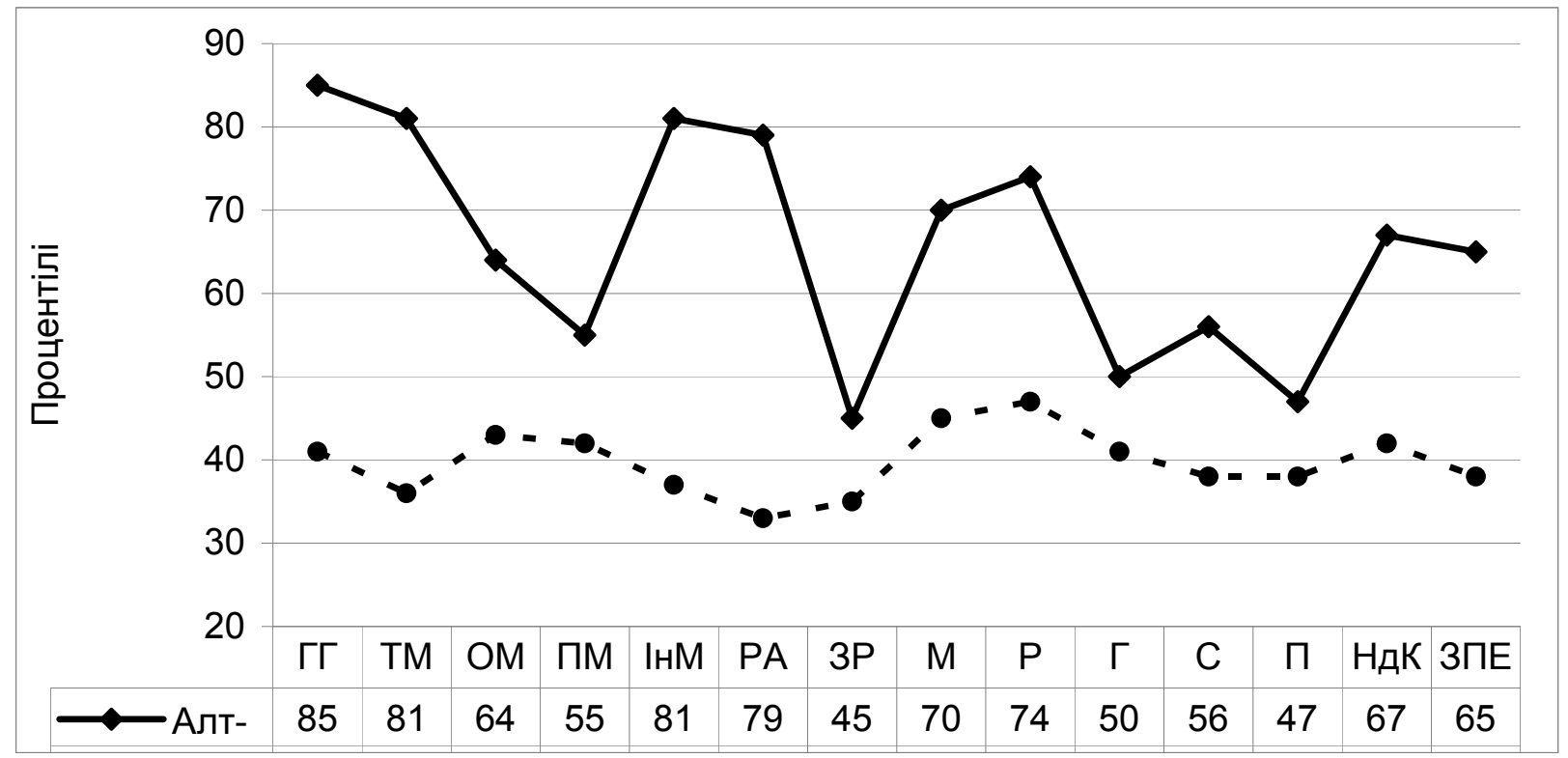

Рис. 1. Профілі показників експресії двох груп осіб: неалекситимічного типу особистості (не схильних до алекситимії - Алт-) та алекситимічного типу особистості (тенденція до алекситимії - Алт+)

Примітка: скорочення а) канали експресії: ГГ - гучність голосу, ТМ - темп мови, ОМ - образність мови, ПМ - помилки мови, Інт - інтонаційний вираз мови, РА - загальна рухова активність, ЗР - зайві рухи, М - міміка; б) виразність чотирьох емоційних 
модальностей: Р - радість, Г - гнів, С - страх, П - печаль; в) НдК - експресія без диференціації каналів, ЗПЕ - загальний показник експресивності особистості.

На рис. 1 на осі абсцис розташовані показники експресії, на осі ординат - їх значення, що виражені у процентилях. Значення кожного показника експресії відповідає розміру середнього арифметичного всіх представників кожної групи.

При аналізі цих профілів нас цікавлять не тільки специфіка експресії означених груп осіб, а й відмінності, що виявляються при порівнянні цих профілів. Візуальний аналіз профілів експресії групи осіб неалекситимічного типу (Алт-) та алекситимічного типу особистості (Алт+) виявляє розбіжності між такими однойменними показниками, як ГГ гучність голосу, ТМ - темп мови Інт - інтонаційний вираз мови, РА - загальна рухова активність, Р - радість. При порівнянні однойменних показників за допомогою застосування t-критерія Ст'юдента (див. табл. 2) виявлено ще два показника, що значимо відрізняються за рівнем виразу - це показник М (міміка) та ЗПЕ (загальний показник експресивності особистості).

Таблиця 2

Значення t-критерія Ст'юдента між однойменними показниками експресії двох груп осіб, що порівнюються

\begin{tabular}{|c|c|c|c|c|c|c|c|}
\hline 1. Група & \multicolumn{7}{|c|}{ Показники експресивності двох груп, які порівнюються } \\
\hline $\begin{array}{l}\text { Алт- } \\
\text { 2. Група } \\
\text { Алт+ }\end{array}$ & $\Gamma \Gamma$ & TM & Iнт & PA & $\mathrm{P}$ & $\mathrm{M}$ & ЗПЕ \\
\hline t-критерій & $6,450 * * *$ & $3,695 * *$ & $6,605 * * *$ & $3,780 * *$ & $3,128 * *$ & $2,294 *$ & $2,208^{*}$ \\
\hline
\end{tabular}

Примітка: 1) позначення «***» вказує на високий рівень значущості $\rho \leq 0,001$; «**» - рівень значущості $\rho \leq 0,01$; «*»- рівень значущості $\rho \leq 0,05$.

Візуальний аналіз профілів (див. рис. 1), підтверджується значеннями t-критерія Ст'юдента (див. табл. 2), що свідчать про більш активну, яскраву та енергійну експресію у представників першої групи осіб (Алт-) з неалекситимічним типом особистості (наявність додатного знаку перед числовими значеннями t-критерія інформує про те, що конкретний однойменний показник за рівнем вище у першій групі у порівнянні з другою). Розглянемо профілі кожної групи окремо.

Деякі показники профіля групи осіб з неалекситимічним типом тяжіють до додатного полюсу, крім показників ЗР (зайві рухи), Г (гнів) та П (печаль), значення яких розташовані біля середньої лінії ряду. Представники цієї групи характеризують свій голос як гучний (ГГ), інтонаційно виразний (ІнM), темповий (ТM), що свідчить про високу голосову техніку. Володіння інтонацією мови дозволяє особистості правильно побудувати промову, передати ії смисл і власні почуття, що емоційно забарвлює зміст промови. Особи, котрі належать до групи Алт- демонструють також високі значення показника ТМ (темп мови), що характеризує швидкість, енергійність 3 якою людина вимовляє весь текст у цілому, окремі слова, речення. Ці особи схильні до рухів, що демонструють радість (Р) і відмічають у себе загальну рухову активність.

Що стосується представників групи Алт+, тобто тих, які належать до групи ризику (тенденція до алекситимічного типу особистості), то їх профіль не має виразу, не демонструє яскравий портрет експресії, що може бути пов'язаним із відсутністю у даній вибірці осіб з явною алекситимією. Профіль групи таких осіб (схильних до алекситимії - 
Алт+) розташований переважно у від'ємному полюсі (у просторі другого квартіля розподілу) і має більш згладжений вигляд, що може свідчити про слабку суб'єктивну диференційованість показників експресії. Вочевидь, представники цієї групи, на відміну від профіля групи осіб, які не схильні до алекситимії (група Алт-), значно менше уваги приділяють світу своїх емоцій та їх зовнішнім виразам.

Загалом можна стверджувати, що представники групи з неалекситимічним типом особистості здатні до розуміння й контролю своїх експресивних проявів, вони більш інформовані щодо своїх емоцій, сміливіші в їхній оцінці і не дотримуються соціальної бажаності. Тенденція до збільшення рівня алекситимії гальмує здатність особистості до експресивних виразів власних емоційних переживань, а прояви успішного розпізнавання власної експресії демонструють особи, котрі не виявили схильності до алекситимії.

\section{Висновки}

1. Дослідження спрямоване на вивчення особливостей розпізнавання власних емоційних станів і розуміння власного експресивного репертуару осіб, котрі різняться схильністю до алекситимії. Експресія розуміється як мова виразності, що закладена в міміці людини, інтонації голосу, в пантоміміці, жестах, рухах, позах, ході людини тощо. Один із аспектів експресії - це зовнішній прояв емоцій, індикатор, за допомогою якого можна судити про особливості переживань людини. Розкрито поняття алекситимії як чинника розуміння емоцій. Алекситимія розглядається як нездатність сприймати, відчувати і називати словом (lexis) свої почуття, свої емоції (thymos).

2. Для вимірювання показників зовнішніх емоційних виразів застосовувався тестопитувальник «Експрес-діагностика емоційної експресії» (самооцінний варіант), вивчення алекситимії здійснювалося Торонтською алекситимічною шкалою із 26 пунктів (Toronto Alexithymia Scale - TAS-26). Здійснено пошук закономірних взаємозв'язків між показниками феноменів, що вивчаються. Емпірично встановлена наявність значимого від’ємного зв'язку між показниками виразної експресії та алекситимії.

3. За допомогою методу «асів» і «профілів» виявлено осіб схильних і не схильних до алекситимії, визначено та порівняно особливості їх експресії, що презентовані графічно. Подана порівняльна характеристика експресії представників двох груп осіб. Емпірично встановлено, що представники неалекситимічного типу особистості мають більш високі показники експресії, виявляють здібності до успішного розпізнавання власної експресії порівняно з особами, що перебувають у групі ризику (тяжіння до алекситимічного типу особистості).

4. Доведено, що тенденція до збільшення рівня алекситимії гальмує здатність особистості до експресивних проявів власних емоційних переживань. Доведено, що схильність до алекситимії є одним із психологічних чинників здатності особистості не тільки розуміти власні емоції, а й здатності ідентифікувати та використовувати власний експресивний репертуар і його можливості.

Перспективу подальших досліджень передбачається спрямувати на пошук психологічних чинників непатологічної алекситимії, на розробку і адаптацію адекватного психодіагностичного інструментарію, та на вивчення індивідуально-психологічних особливостей осіб з алекситимічним типом особистості. 


\section{Література}

1. Андреева, И.Н. (2011). Эмоциональньй интеллект как феномен современной психологии. Новополоцк : ПГУ. Режим доступу: http://libed.ru/knigi-nauka/362713

2. Есин, И.Б. (2006). Специчфика эмоционального слуха и эмоциональной экспрессивности речи у представителей разных профессий. (Дис. канд. психол. наук). Москва. Режим доступу: https://www.dissercat.com/content/spetsifika-emotsionalnogo-slukha-iemotsionalnoi-ekspressivnosti-rechi-u-predstavitelei-razl

3. Жежелевская, А.А. (2014). Точность распознавания эмоциональной экспрессии в устном иноязычном сообщении. (Дис. канд. психол. наук). Москва. Режим доступу: https://www.dissercat.com/content/tochnost-raspoznavaniya-emotsionalnoi-ekspressii-vustnom-inoyazychnom-soobshchenii

4. Корнева, Т.В., \& Бажин, Е.Ф. (1977). О роли профессионального и полового факторов в аудиторской оценке эмоционально окрашенной речи. Проблемы космической биологии, 34, 293-299.

5. Лабунская, В.А., \& Дроздова, И.И. (2003). Социально-психологические особенности субъектов педагогического общения с различным типом соотношения успешности кодирования и интерпретации экспрессии эмоциональных состояний. СевероКавказский психологический вестник, 1, 248-259.

6. Мацумото, Д. (2003). Психология и культура. СПб. : Питер. Режим доступу: https://bok.xyz/book/3076507/ca5f7a

7. Непп, М., \& Холл, Д. (ред.) (2006). Невербальное общение. Полное руководство. СПб. : Прайм -ЕВРОЗНАК. Режим доступу: https://lektsia.com/11x5076.html

8. Носенко, Е.Л., \& Коврига, Н.В. (2003). Емоційний інтелект: концептуалізаиія феномену, основні функиіï. Київ: Вища школа. Режим доступу: $\underline{\mathrm{https} / / \mathrm{b}-}$ ok.xyz/book/3303660/77234f

9. Овсянникова, В.В. (2014). Влияние эмоционального состояния на распознавание эмоций. Психология. Журнал Высшей школье экономики, 11, 1, 86-101. https://doi.org/10.17323/1813-8918-2014-1-86-101

10. Ольшанникова, А.Е. (1981). Диагностические возможности опросника по эмоциональной эмоциональной экспрессии. Проблемь дифференциальной психофизиологии. Москва : Педагогіка. (124-136).

11. Рейковский, Я. (1979). Экспериментальная психология эмоџий. Москва : Прогрес. Режим доступу: http://vprosvet.ru/biblioteka/eksperimentalnaya-psihologiya-emocij

12. Санникова, О.П. (1982). Соотношение устойчивых индивидуально-типических особенностей эмоциональности и общительности. Дис. канд. психол. наук. Москва.

13. Санникова, О.П. (2003). Феноменология личности: Избранные психологические труды. Одесса : СМИЛ.

14. Санникова, О.П. (2009). Реабилитация методики эмоциональной экспрессии. Наука ц̌ освіта. Спецвипуск. «Психологія особистості: теорія, досвід, практика», 8, 4-7.

15. Санникова, О.П. (2017). Психологічна проникливість як інструмент осягнення сутності іншої людини. Проблеми сучасної психологї: зб. наук.пращь Державного вищого навчального закладу «Запорізький національний університет» та Інституту психологіі імені Г.С.Костюка НАПН Украйни, 2(10), 119-123 Режим доступу: http://nbuv.gov.ua/UJRN/pspz_2016_2_21.

16. Ekman, P., Friesen, W., \& Tomkins, S. (1971). Facial affect scoring technigues: a first validity studi. Semiotika, 3, 37-58. https://doi.org/10.1515/semi.1971.3.1.37.

17. Izard, C.E. (1971). The face of emotion. N.Y. : Appleton.

18. Lane, R.D., Sechrest L., Reidel R. et al. (1996). Impaired verbal and nonverbal emotion recognition in alexithymia. Psychosomatic Medicine, 58, 203-210.

19. Luebbe, A.M., Fussner, L.M., Kiel, E. J., Early, M.C., \& Bell, D.J. (2013). Role of adolescent and maternal depressive symptoms on transactional emotion recognition: Context and State 
Affect Matter. Emotion, 13 (6), 1160-1172. https://doi.org/10.1037/a0033923

20. McClure, E.B. (2000). A meta-analytic review of sex differences in facial expression processing and their development in infants, children, and adolescents. Psychological Bulletin, 126, 424-453. https://doi.org/10,1037/0033-2909.126.3.424

21. Nemiah, J.C., Freyberger, H., \& Sifneos, P.E. (1976). Alexithymia: A view of the psychosomatic process. Modern trends in psychosomatic medicine / O.W. Hill (Ed.). London: Butterworths, III, 430-439.

22. Suslow, T., \& Junghanns, K. (2002). Impairments of emotion situation priming in alexithymia. Personality and Individual Differences, 32(3), 541-550. https://doi.org/10.1016/S0191-8869(01)00056-3

23. Taylor, G.J., Bagby, R.M., \& Parker, J.D.A. (1997). Disorders of affect regulation: Alexithymia in medical and psychiatric illness. Cambridge: Cambridge University Press. https://doi.org/10.1017/CBO9780511526831

24. Taylor, G.J., Ryan, D., \& Bagby, R.M. (1985). Toward the development of a new self-report alexithymia scale // Psychother. Psychosom. Vol. 44. P. 191-199. https://doi.org/10.1159/000287912

\section{References}

1. Andreeva, I.N. (2011). Emotsionalnyiy intellekt kak fenomen sovremennoy psihologii [Emotional intelligence as a phenomenon of modern psychology]. Novopolotsk : PGU. Retrieved from http://libed.ru/knigi-nauka/362713 [in Russian].

2. Esin, I.B. (2006). Spetsifika emotsionalnogo sluha i emotsionalnoy ekspressivnosti rechi u predstaviteley raznyih professiy [The specifics of emotional hearing and emotional expressiveness of speech in representatives of different professions]. Candidate s thesis. Moskva. Retrieved from https:/www.dissercat.com/content/spetsifika-emotsionalnogoslukha-i-emotsionalnoi-ekspressivnosti-rechi-u-predstavitelei-razl [in Russian].

3. Zhezhelevskaya, A.A. (2014). Tochnost raspoznavaniya emotsionalnoy ekspressii v ustnom inoyazyichnom soobschenii [Emotional recognition accuracy expression in oral foreign language]. Candidate's thesis. Moskvar Retrieved from https://www.dissercat.com/content/tochnost-raspoznavaniya-emotsionalnoi-ekspressii-vustnom-inoyazychnom-soobshchenii [in Russian].

4. Korneva, T.V., \& Bazhin, E.F. (1977). O roli professionalnogo i polovogo faktorov v auditorskoy otsenke emotsionalno okrashennoy rechi [On the role of professional and sexual factors in the audit assessment of emotionally colored speech]. Problemyi kosmicheskoy biologii - Problems of Space Biology, 34, 293-299 [in Russian].

5. Labunskaya, V.A., \& Drozdova, I.I. (2003). Sotsialno-psihologicheskie osobennosti sub'ektov pedagogicheskogo obscheniya s razlichnyim tipom sootnosheniya uspeshnosti kodirovaniya $\mathrm{i}$ interpretatsii ekspressii emotsionalnyih sostoyaniy [Socio-psychological characteristics of the subjects of pedagogical communication with a different type of correlation of the success of coding and interpretation of the expression of emotional states]. Severo-Kavkazskiy psihologicheskiy vestnik - North Caucasian Psychological Bulletin, 1, 248-259. [in Russian].

6. Matsumoto, D. (2003). Psihologiya i kultura [Psychology and culture]. SPb.: Piter. Retrieved from https://b-ok.xyz/book/3076507/ca5f7a [in Russian].

7. Nepp, M., \& Holl, D. (Ed.) (2006). Neverbalnoe obschenie. Polnoe rukovodstvo [Non-verbal communication. The complete guide]. SPb. : Praym - EVROZNAK. Retrieved from https://lektsia.com/11x5076.html [in Russian].

8. Nosenko, E.L., \& Kovryha, N.V. (2003). Emotsiinyi intelekt: kontseptualizatsiia fenomenu, osnovni funktsii [Emotional intelligence: conceptualization of the phenomenon, basic functions]. Kyiv : Vyshcha shkola. Retrieved from https://b-ok.xyz/book/3303660/77234f [in Ukrainian]. 
9. Ovsyannikova, V.V. (2014). Vliyanie emotsionalnogo sostoyaniya na raspoznavanie emotsiy [The influence of emotional state on recognition of emotions]. Psihologiya. Zhurnal Vyisshey shkolyi ekonomiki - Psychology. Journal of the Higher School of Economics, 11, 1, 86-101. https://doi.org/10.17323/1813-8918-2014-1-86-101 [in Russian].

10. Olshannikova, A.E. (1981). Diagnosticheskie vozmozhnosti oprosnika po emotsionalnoy emotsionalnoy ekspressii [Diagnostic capabilities of the questionnaire for emotional emotional expression]. Problemyi differentsialnoy psihofiziologii-Problems of differential psychophysiology. Moskva : PedagogIka, pp. 124-136 [in Russian].

11. Reykovskiy, Y. (1979). Eksperimentalnaya psihologiya emotsiy [Experimental psychology of emotions]. Moskva : Progres. Retrieved from http://vprosvet.ru/biblioteka/eksperimentalnaya-psihologiya-emocij [in Russian].

12. Sannikova, O.P. (1982). Sootnoshenie ustoychivyih individualno-tipicheskih osobennostey emotsionalnosti i obschitelnosti [Correlation of stable individual-typical features of emotionality and sociability]. Candidate s thesis. Moskva [in Russian].

13. Sannikova, O.P. (2003). Phenomenology of personality: Selected psychological works [Phenomenology of personality: Selected psychological works]. Odessa: SMIL [in Russian].

14. Sannikova, O.P. (2009). Reabilitatsiya metodiki emotsionalnoy ekspressii [Rehabilitation of emotional expression techniques]. Nauka y osvIta - Science and education, 8, 4-7 [in Russian].

15. Sannykova, O.P. (2017). Psykholohichna pronyklyvist yak instrument osiahnennia sutnosti inshoi liudyny [Psychological insight as a tool for understanding the essence of another person]. Problemy suchasnoi psykholohii - Problems of modern psychology: zbirnyk naukovykh prats Derzhavnoho vyshchoho navchalnoho zakladu «Zaporizkyi natsionalnyi universytet» ta Instytutu psykholohii imeni H. S. Kostiuka NAPN Ukrainy, 2(10), 19-123. Retrieved from http://nbuv.gov.ua/UJRN/pspz 2016221 [in Ukrainian].

16. Ekman, P., Friesen, W., \& Tomkins, S. (1971). Facial affect scoring technigues: a first validity studi. Semiotika, 3, 37-58. https://doi.org/10.1515/semi.1971.3.1.37

17. Izard, C.E. (1971). The face of emotion. N.Y. : Appleton.

18. Lane, R.D., Sechrest, L., Reidel, R. et al. (1996). Impaired verbal and nonverbal emotion recognition in alexithymia. Psychosomatic Medicine, 58, 203-210.

19. Luebbe, A.M., Fussner, L.M., Kiel, E.J., Early, M.C., \& Bell, D.J. (2013). Role of adolescent and maternal depressive symptoms on transactional emotion recognition: Context and State Affect Matter. Emotion, 13 (6), 1160-1172. https://doi.org/10.1037/a0033923

20. McClure, E.B. (2000). A meta-analytic review of sex differences in facial expression processing and their development in infants, children, and adolescents. Psychological Bulletin, 126, 424-453. https://doi.org/10,1037/0033-2909.126.3.424

21. Nemiah, J.C., Freyberger, H., \& Sifneos, P.E. (1976). Alexithymia: A view of the psychosomatic process. Modern trends in psychosomatic medicine / O.W. Hill (Ed.). London: Butterworths, III, 430-439.

22. Suslow, T., \& Junghanns, K. (2002). Impairments of emotion situation priming in alexithymia. Personality and Individual Differences, 32(3), 541-550. https://doi.org/10.1016/S0191-8869(01)00056-3

23. Taylor, G.J., Bagby, R.M., \& Parker, J.D.A. (1997). Disorders of affect regulation: Alexithymia in medical and psychiatric illness. Cambridge: Cambridge University Press. https://doi.org/10.1017/CBO9780511526831

24. Taylor, G.J., Ryan, D., \& Bagby, R.M. (1985). Toward the development of a new self-report alexithymia scale// Psychother. Psychosom. Vol. 44. P. 191-199. https://doi.org/10.1159/000287912 


\title{
FEATURES OF EXPRESSION OF PEOPLE WITH DIFFERENT
}

TENDENCY TO ALEXITHYMIA

\author{
Olga Sannikova
}

Doctor of Sciences in Psychology, Professor, Head of the Department of General and Differential Psychology

South Ukrainian National Pedagogical Ushynskyi University

26, Staroportofrankivska Str., Odesa, Ukraine, 65020

osanniland@gmail.com, http://orcid.org/0000-0003-3961-2103

\author{
Ren Zhong \\ Postgraduate student of the Department of General and Differential Psychology \\ South Ukrainian National Pedagogical Ushynskyi University \\ 26, Staroportofrankivska Str., Odesa, Ukraine, 65020 \\ 903843223@qq.com
}

\begin{abstract}
The article is devoted to the problem of recognition of the own emotional experiences and their external expressions. The tendency of the individual to recognize emotions through the perception of expression is regarded as a well-established, multi-component, integral property that provides accuracy, adequacy of understanding their emotional experiences and experiences of another. The relevance of the development of the problem is related to the lack of social connections, lack of experience in recognizing emotions, especially in the situation of development of Internet Communications, which leads to the reduction of emotional vocabulary of a modern man. The process of social adaptation is impossible without the ability of the individual to understand and differentiate emotions. This leads to the need to study the ability of the individual to adequately determine their emotional states and understand their expressive repertoire. This study is based on the suggestion that difficulties in recognizing the emotions and expressing them may be associated with a different personality tendency to alexithymia. Alexithymia is regarded as an inability to perceive, feel and call the word (lexis) feelings, their emotions (thymos).

The aim of the article is to study the ability to understand and recognize the expressive show of emotions in persons with different tendency to alexithymia. The concept of alexithymia as a factor of understanding of emotions was revealed; the correlation between the parameters of the variables was explored; persons who are prone and are not prone to alexithymia were defined and the peculiarities of their expression were defined and compared. The presence of the significant negative connection between the indicators of expressive expression and alexithymia was empirically established. It was shown that the tendency to increase the level of alexithymia inhibits the ability of personality to expressive manifestations of their emotional experiences, and manifestations of successful recognition of their expression show the persons who have not found propensity to alexithymia. It was proved that the tendency to alexithymia is one of psychological factors of personality"s ability not only to understand the emotions, but also to identify and use the expressive repertoire, its possibilities and resources.
\end{abstract}

Key words: alexithymia, expression, emotions, alexithymia type, non-alexithymia type, recognition of emotions. 